\title{
Management System for Dam-Break Hazard Mapping in a Complex Basin Environment
}

\author{
Jian Mao ${ }^{1}$, Shandong Wang ${ }^{2}$, Jianhua $\mathrm{Ni}^{1}$, Changbai $\mathrm{Xi}^{1}$ and Jiechen Wang ${ }^{1,3,4, *}$ \\ 1 Department of Geographic Information Science, Nanjing University, Nanjing 210093, China; \\ nh146@163.com (J.M.); neejianhua@126.com (J.N.); xicb11@gmail.com (C.X.) \\ 2 Department of Earth Science and Engineering, Hohai University, Nanjing 211100, China; wsd0605@126.com \\ 3 Jiangsu Provincial Key Laboratory of Geographic Information Science and Technology, \\ Nanjing 210093, China \\ 4 Jiangsu Center for Collaborative Innovation in Geographical Information Resource Development and \\ Application, Nanjing 210093, China \\ * Correspondence: wangjiechen@nju.edu.cn; Tel.: +86-025-8359-2681
}

Academic Editors: Jason K. Levy and Wolfgang Kainz

Received: 16 February 2017; Accepted: 24 May 2017; Published: 1 June 2017

\begin{abstract}
Flood disasters from dam breaks cause serious loss of human life and immense damage to infrastructure and economic stability. The application of Geographic Information System technology integrated with hydrological modeling for mapping flood-inundated areas and depth can play a momentous role in further minimizing the risk and possible damage. In the present study, base terrain data, hydrological data, and dam engineering data were integrated using the MIKE-21 dam-break model to analyze flood routing under the most serious scenarios. A deterministic approach was used to calculate the hydraulic elements of dam breakage during a flood. Additionally, the hydraulic elements generated by the MIKE-21 dam-break model (a modelling system for estuaries, coastal waters, and seas) -including flood depth, submersion time, and flow direction-were integrated with a digital elevation model of the site downstream of the dam in order to map the possible affected areas. Using an empirical model in addition to using the superimposition of dam flood calculation results and the social and economic survey data, dam damage assessment was implemented. In accordance with a relevant standard, the flood risk mapping guidelines and a set of client/server structures were developed for a management system for dam-break hazard mapping of the Foziling reservoir. The simulation data and the study results can provide a scientific basis for emergency management of the reservoir and provide a socio-economic framework for downstream areas.
\end{abstract}

Keywords: dam break analysis; MIKE-21; GIS; flood mapping; hydraulic elements; China

\section{Introduction}

The construction of reservoirs and dams may provide society with a number of advantages, such as water source security, water and sediment diversion, power generation, and irrigation. However, accidents occurring downstream of a dam break have disastrous effects on society, the economy, and the environment. Statistics from the China Institute of Water Resources and Hydropower Research indicate that 3498 dam failure events occurred in China from 1954 to 2006 [1,2]. The increasing focus on dam safety has revealed major concerns for technicians and individuals responsible for designing, licensing, constructing, and managing such structures [3,4]. A systematic assessment of the hazards posed by possible dam failures is useful for disaster planning, emergency response, and flood warnings [5]. However, research on hazard planning, warning systems, and loss assessment considering potential dam failures has not yet been established. 
Compared with other types of flood, floods caused by dam failure are characterized by instant occurrence, vast quantity of flow, and powerful impulsive force. During a dam break, the flood propagation is influenced by a number of factors, such as failure modes, dyke shapes, sediment transport, slope stability, as well as the propagation processes of dykes and related hydrologic and hydraulic factors in the lower reaches [6]. Generally, there are two methods of flood routing: the hydrologic approach (e.g., the Muskingum method), and the hydrodynamic approach (e.g., solving Saint-Venant equations) [7-10]. During dam break floods, watershed concentration has little effect on the total damage, as this type of flood is characterized by abruptness and high destructiveness. Therefore, the hydrologic approach is not considered appropriate for calculating the related parameters. Although there are many examples of dam failures in history, unfortunately, only few of them are well documented and maintained. Existing records are extremely insufficient, and most of them were documented by visual observation, implying that they are highly subjective and uncertain. The hydrodynamic approach is now being widely and frequently applied in the evolution analysis of dam break floods [11-14].

Some studies $[15,16]$ on dam break floods have focused on watershed hydrology with the assumption that, in hazard assessment, the future behavior of dam breaks can be predicted on the basis of the past behavior of such events. Pilotti et al. [11] compared one-dimensional (1D) and two-dimensional (2D) shallow water models for dam-break wave propagation in alpine regions. Jene et al. [4] used a hydraulic model, called FLDWAV (a generalized flood routing model) to determine the hydraulic characteristics of a flood, including the discharge, speed, elevation, and depth of the flood at various times and at various distances downstream of the dam. Yin et al. [12] used a 2D spatial distribution CA model (a constrained cellular automata model) and simulated the spatiotemporal process of a dam-break flood routing under the discrete time and spatial framework. 1D models (MIKE-11; HEC-RAS) require large amounts of data for the water course profile, whereas 2D models (DAMBRK; Delft-FSL; Telemac 2D; MIKE21) require the continuous representation of topography in the form of a digital surface model [17-21]. The profile data required by the 1D model must be obtained not only from within the river courses, but also in a buffer from both banks of the river in order to ensure the accuracy and precision of the results.

In recent years, many scholars have attempted to combine hydrodynamic models with $3 S$ technology ( $3 \mathrm{~S}$ technology is an umbrella name given to the remote sensing, geography information systems, and global positioning systems) [22-24]. In these studies, they have also tried to apply surveying, mapping, and geographic information science-related technology and methodology to hydrological calculation models to provide hydraulic data with highly precise base terrain and socioeconomic data. In addition, the results were utilized in several processes, such as building a dam-break flood emergency management system [3], assessing and analyzing the impacts of dam-break floods [5,25], risk assessment of dam-breaks [26], constructing a 3D visualization system of dam-break flood routing, and studying the spatiotemporal variations of dam-break floods by the visualization simulation method. Mordvintsev et al. [27] presented an environment for simulating different city-evacuation scenarios. It is very important to optimize the utility of the system to improve the feasibility and visualization of the outcomes of dam-break flood calculations.

In this study, the extent of the impacts of dam-break floods on a given complicated catchment was investigated, with the Foziling reservoir and downstream area of Pihe River being taken as an example to verify the results. The Pihe River Basin is found in a complex environment which presently forms a fan-shaped distribution, with the upstream being mountain valley and the downstream being plain terrain. An attempt was made to use a hydrodynamic model coupled with geo-informatics for pre-processing and post-processing of data to simulate the failure of a reinforced concrete multiple-arch dam in a sizeable tributary of the Huai River, Anhui, China. The 2D evolution of flood in a given circumstance of a transient entire dam-break can be simulated using the MIKE21 hydraulic model, as well as by fusion processing multi-source and multi-scale basic geographic information data [28,29]. According to the standards and requirements of flood risk mapping guidelines set by the Ministry 
of Water Resources of China [30], flood risk maps can be plotted using GIS (Geographic Information Systems) technology, with a management system having the ability to be further developed for dam-break hazard mapping [24,31].

\section{Study Area}

The Foziling reservoir (Figure 1) is located upstream of the Pihe River, which is a sizeable branch of the Huai River. Regarding the terrain through which the river flows, $70.4 \%$ are mountains, $23.2 \%$ are hilly areas, and $6.4 \%$ are plains, with an overall drop of $362.1 \mathrm{~m}$ and an average gradient ratio of $1.46 \%$. The geographic coordinates are longitude $116.16^{\circ} \mathrm{E}, 31.16^{\circ} \mathrm{N}$, which is located $17 \mathrm{~km}$ away from Huoshan County, Anhui Province. The catchment area of the reservoir is $1840 \mathrm{~km}^{2}$. It has a subtropical humid monsoon climate with an average annual temperature of $15.10^{\circ} \mathrm{C}$, average annual sunshine duration of $2084 \mathrm{~h}$, and cross-year average rainfall of $1540 \mathrm{~mm}$. Precipitation is mainly concentrated in the flood season from May to September, accounting for $45.2 \%$ of the annual amount. The cross-year average runoff volume is $1,062,000,000 \mathrm{~m}^{3}$, whereas the cross-year average evaporation is $1349 \mathrm{~mm}$.

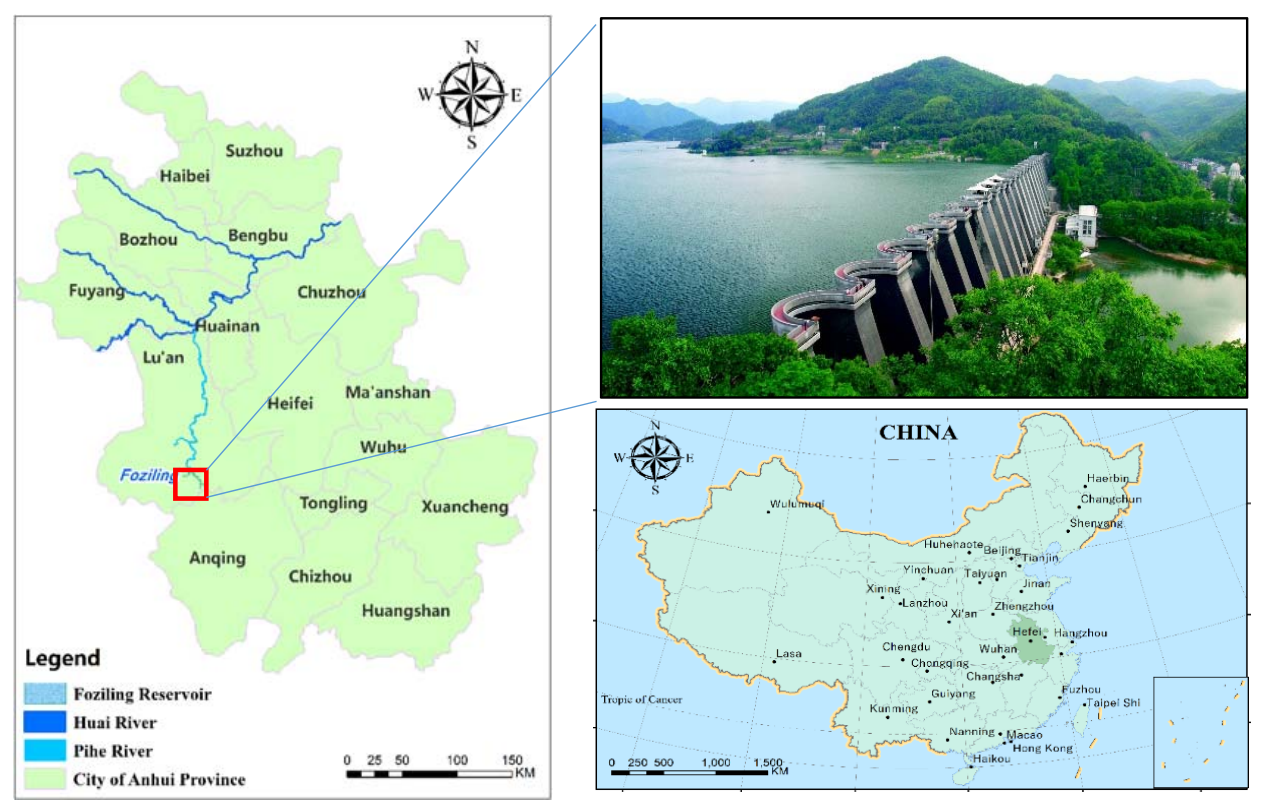

Figure 1. Location of the study area within AnHui Province, Central China.

The Foziling Reservoir Management Office mentions that this multiple-arch dam made of reinforced concrete was constructed in 1952, being the very first one completely designed and constructed by the Chinese people. The total length of the dam is $510 \mathrm{~m}$, but the length of the multiple-arch dam is $413.5 \mathrm{~m}$. The elevation of the dam crest is $129.96 \mathrm{~m}$, while the maximum dam height is $75.9 \mathrm{~m}$. There are three flood discharge outlets with diameters of $1.975 \mathrm{~m}$, separately laid in three dam buttresses numbered 13,14, and 15 . These outlets amount to a maximum discharge volume of up to $225 \mathrm{~m}^{3} / \mathrm{s}$. Six diversion pipes with a total flow of $98.25 \mathrm{~m}^{3} / \mathrm{s}$ are set for the delivery of water for power generation in both old and new plants (Figure 2).

The dam has undergone three major repairs since its completion [32]. The first was from June 1965 to October 1968. The reservoir was emptied, because cracks appeared in the dam body, which resulted in a series of problems occurring in the steel tubes, such as cavitation and vibration. Thus, projects were implemented at the dam and flood discharge tubes, including strengthening of arch pouring, curtain grouting and consolidation grouting. The second one was from June 1982 to June 1986. The height of the dam was increased by $1.5 \mathrm{~m}$ with the addition of one more flood spillway because flood overtopping occurred in July 1969. Consequently, the maximum flood discharge capacity was increased to $7540 \mathrm{~m}^{3} / \mathrm{s}$. The third major repair was from October 2002 to April 2005. 


\begin{tabular}{|c|c|}
\hline \multicolumn{2}{|l|}{ Dam basic situation } \\
\hline River bed level at dam site & $75.9 \mathrm{~m}$ \\
\hline Top elevation of dam & $129.96 \mathrm{~m}$ \\
\hline Length of dam & $510 \mathrm{~m}$ \\
\hline \multicolumn{2}{|l|}{ Reservoir design standard } \\
\hline Maximum water level & $130 \mathrm{~m}$ \\
\hline Total storage & $4.96 \mathrm{Mm}^{3}$ \\
\hline Flood control standard & 1000 year \\
\hline Flood control limited levels & $117.56 \mathrm{~m}$ \\
\hline \multicolumn{2}{|l|}{ Hydrological characteristics } \\
\hline Catchment area & $1840 \mathrm{~km}^{2}$ \\
\hline Maximum annual runoff & $10.62 \mathrm{Mm}^{3}$ \\
\hline Annual average evaporation & $1349 \mathrm{~mm}$ \\
\hline Mean annual precipitation & $1540 \mathrm{~mm}$ \\
\hline Annual average temperature & $15.10^{~ C}$ \\
\hline The average gradient of river & $1.46 \%$ \\
\hline
\end{tabular}

Figure 2. Salient features of the Foziling Reservoir project.

By deformation monitoring, it was found that there was increasing displacement of dam buttresses towards the downstream direction. Despite the first and second reinforcements, serious cracks still developed in the dam, which subsequently identified it as a class III dam (Identified by the reservoir dam safety identification method formulated by the Chinese Ministry of Water Resources). This class implies that the flood prevention standard was not met and risks still existed. Therefore, the entire dam was reinforced using some new techniques, which actually enhanced the stability safety factor and the corresponding flood prevention capability.

\section{Methodology}

\subsection{Research Framework}

To accurately simulate the propagation of different schemes after the occurrence of a dam-break flood and to perform dam-break hazard mapping, there needs to be integration of data, such as hydrologic data, terrain data, and flood disaster emergency treatment project data (including safety route, position of warehouse containing flood control materials, hospital, and hedging point) [33]. In this study, 1D and 2D dam-break hydraulic models were combined by considering information from the hydraulic elements, which was based on the spatial processing of multi-source and multi-scale geospatial data in addition to socio-economic investigation data. According to the standards [30] set by the Ministry of Water Resources of China, dam-break hazard maps were plotted, such as water depth distribution map and maximum flood submerging range (Figure 3).

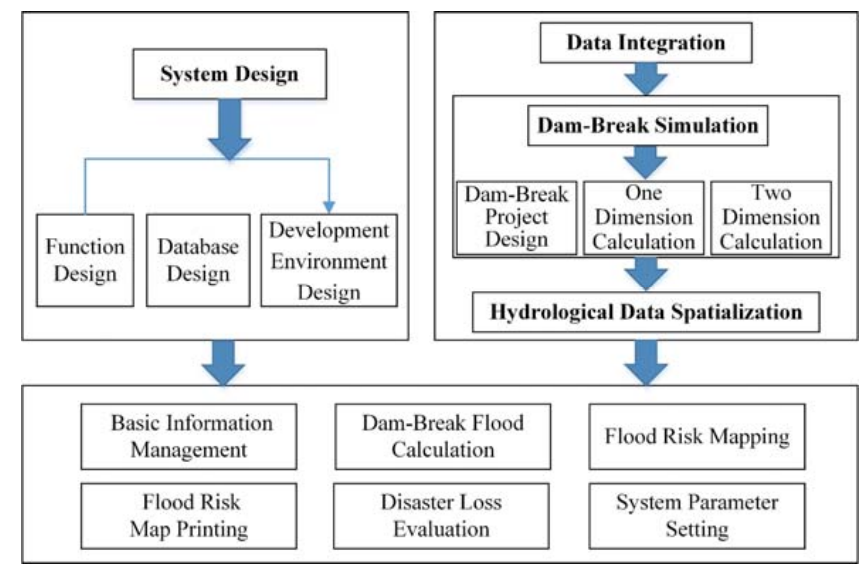

Figure 3. Research route and framework for dam-break hazard mapping management. 


\subsection{Data Integration}

Multi-scale, multi-source, and multi-format spatial and attribute data were integrated in the dam-break simulation and risk analysis system. Normalization of the multiple source data is a basic problem in flood risk mapping, which involves a series of key techniques such as construction of basic database of dam-break disasters, analysis of the spatial characteristics of hydrologic data, and format conversion between DWG files and shapefiles.

\subsubsection{Establishing Database for Dam-Break Hazard Mapping}

Database establishment of dam-break hazard mapping involved the following aspects of data (Table 1):

Table 1. Categories of dam-break hazard data.

\begin{tabular}{lll}
\hline Categories & Data Contents \\
\hline & Basic geographical data & $\begin{array}{l}\text { Basic arrow data on geological information, including large-scale } \\
\text { administration divisions, roads, lake and water systems, and lattice } \\
\text { spatial data for the digital elevation model }\end{array}$ \\
\cline { 2 - 3 } Current data & $\begin{array}{l}\text { Measurement data } \\
\text { Hydrologic data }\end{array}$ & $\begin{array}{l}\text { River cross-section data obtained from digital field maps for plotting } \\
\text { key areas } \\
\text { Type of dam/length/dead storage/design storage/upland water } \\
\text { flow/upstream water depth }\end{array}$ \\
\cline { 2 - 3 } & Socio-economic survey data & $\begin{array}{l}\text { Population/cultivated area/industrial and commercial enterprises/gross } \\
\text { floor area/infrastructure }\end{array}$ \\
\cline { 2 - 3 } & Documentary information & $\begin{array}{l}\text { Relevant statistical records of historical disasters, photos, and } \\
\text { technical reports }\end{array}$ \\
\hline Historical data & Historical disaster data & $\begin{array}{l}\text { Flood frequency information/catchment point information } \\
\text { (depth/area/duration)/history of disaster losses/historical } \\
\text { hydro-meteorological data }\end{array}$ \\
\hline
\end{tabular}

The processes of producing data from different sources were isolated, meaning that sorting, classification, encoding, and representation of certain objects were different. Therefore, it is necessary to follow national and industrial standards to integrate semantics and unify representation methods, thus allowing the interoperation of multi-source spatial data with a unified principle. With this principle, data formats can be unified by converting different formats of spatial data, inputting attribute data, and spatializing hydrologic data. The unified data format provides the fusion of spatial data with preconditions and assurance. Subsequently, a unified projection and coordinate system can be developed to satisfy the requirements of flood risk mapping guidelines, integrating spatial vector data. After the integration, a spatial data engine can be added to a spatial database with a geodatabase model. Thus, a complete object-oriented relational database management system can be developed, achieving the integrative management of spatial and attribute data in addition to further realizing the systematic design of a database on dam-break hazard mapping.

\subsubsection{Spatializing the Results of Hydrological Calculation}

Flooding results calculated using the 1D and 2D hydraulic models are in text format, which are provided in large amounts of files. Tecplot 360 (Tecplot USA) is usually used to read the results and further visualize them. However, the integration of Tecplot with GIS requires extensive technical knowledge, therefore making it necessary to spatialize the hydraulic data. Through coding, a layer of hydrologic data can be created. The attribute information of each grid includes depth, velocity, and direction.

The specific steps for this approach are shown as follows:

(1) Read the .txt file by coding. 
(2) Traverse the file content, read every element by rows, store the point ID and coordinates in a memtable "datatable1", before storing the information of hydraulic elements and grid point in "datatable2".

(3) Generate a polygon shapefile using the program.

(4) Traverse the elements in each row in datatable2 and find the corresponding point coordinates from datatable1. Generate polygons using the program and type the attribute information into the corresponding generated shapefile.

\subsection{Simulation of Dam Break}

\subsubsection{Simulation of the Breach Flow Process Line}

In dam-break flood routing analyses, the breach flow process was initially simulated. There are two methods for the calculation of the breach flow process. The first involves a detailed algorithm, such as the characteristic line method and transient method. These methods are used less often in practical engineering designs because of the complicated calculations, with simplified methods being commonly used in engineering design [34,35]. The Foziling dam is a rigid dam, meaning that the type of dam break is instantaneous collapse of the entire structure in general [36]. The broad-crested weir flow formula [36] was selected in this study to calculate the maximum flow during dam breaks, by considering the algorithm on the basis of maturity and the scope of application:

$$
Q_{m}=k B \sqrt{g} H_{0}^{\frac{3}{2}}
$$

where $Q_{m}$ is the maximum flow of dam-break $\left(\mathrm{m}^{3} / \mathrm{s}\right), B$ is the length of the dam $(\mathrm{m}), H_{0}$ is the upstream water depth before the dam-break $(\mathrm{m})$, and $g$ is gravitational acceleration $\left(\mathrm{m} / \mathrm{s}^{2}\right)$.

The time required for emptying the reservoir during dam-break flood was calculated considering the maximum flow, total reservoir capacity and season. According to the principle of water balance, the total time for emptying the reservoir is given as:

$$
T=K\left(\frac{W}{Q_{m}-Q_{0}}\right)
$$

where $T$ is the emptying time (s), $K$ is the generalized curve shape factor. When the dyke flow curve is a quadratic parabola, $K=3.5$. When the dyke flow curve is a biquadratic parabola, $K=4 . W$ is the reservoir capacity before the dam break $\left(\mathrm{m}^{3}\right)$ and $Q_{0}$ is the upland water flow $\left(\mathrm{m}^{3} / \mathrm{s}\right)$.

The breach flow process line can be generalized into four parabolas.

$$
Q_{t}=\left(1-\left(\frac{t}{T}\right)^{\frac{1}{4}}\right)\left(Q_{m}-Q_{0}\right)+Q_{0}
$$

where $Q_{t}$ is the flow at the $t$ moment after the dam-break begins $\left(\mathrm{m}^{3} / \mathrm{s}\right)$.

In this paper, the breach flow process of the Foziling reservoir during the floor season was simulated, and the total collapse conditions were estimated according to the most dangerous principle combined with the fact that rigid dams often exhibit instantaneous collapse of the entire structure. In order to improve the efficiency of the dam-break calculation, the author developed an automated dam-break flood calculation system (Figure 4) which realized the automatic calculation and graphical performance of multi-parameter, multi-condition flow and collapse time. These improved the efficiency and visualization of the flow rate calculation. 


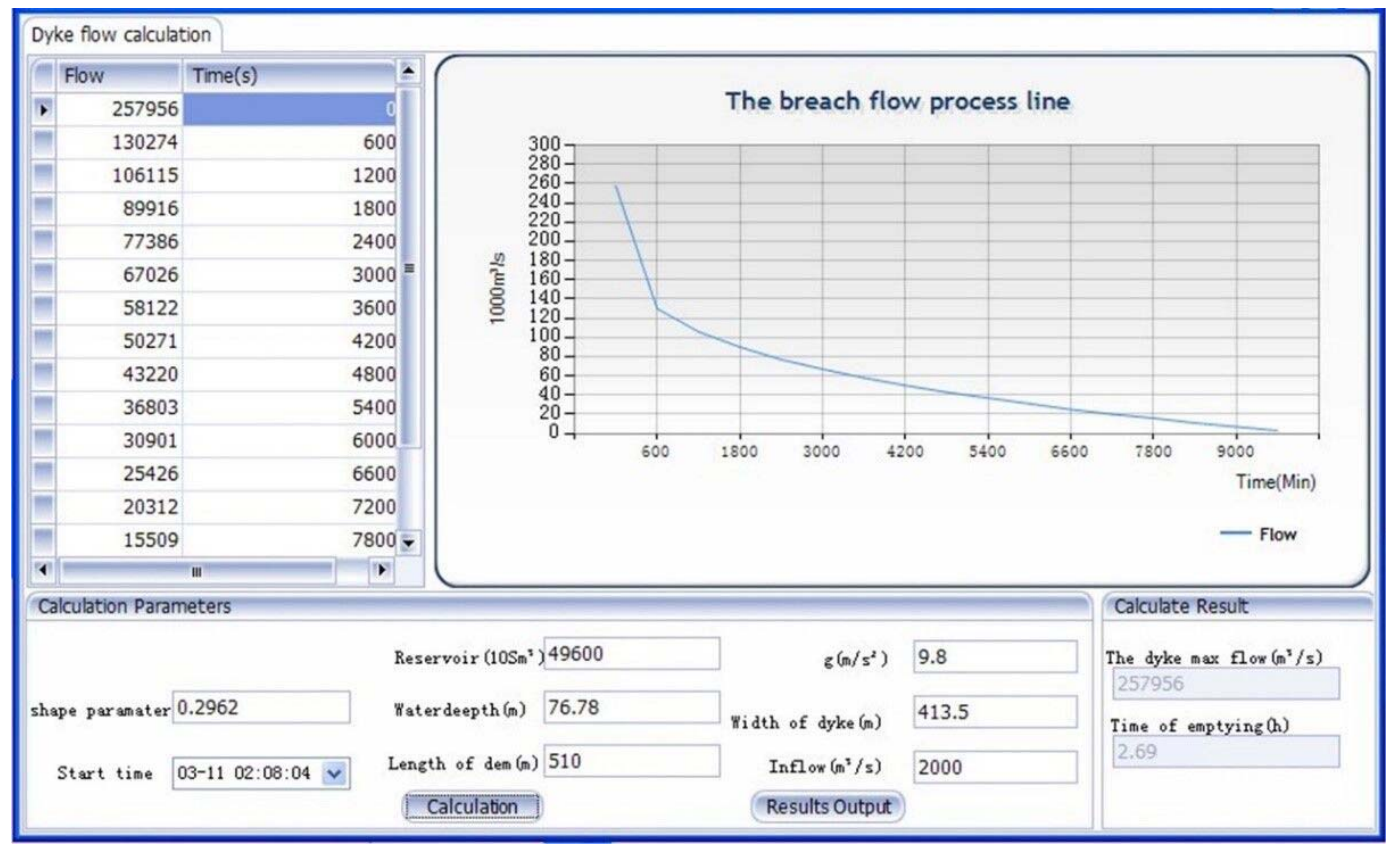

Figure 4. Simulation of the breach flow process line.

\subsubsection{Two-Dimensional Analysis of Dam-Break Flood Evolution}

Many methods-such as the DAMBRK (The NWS dam-break flood forecasting model) and HEC-RAC hydraulics models (River Analysis System is an integrated system of software, designed for interactive use in a multi-tasking environment) [17] (U.S. Army Corps of Engineers, Washington, USA) — can be used to analyze the two-dimensional evolution of dam-break floods. MIKE21 is a series of water dynamics calculation software developed by the Institute for Water and Environment (Danish Academy of Technical Sciences, Lyngby, Danish). MIKE FLOOD is a dynamic toolbox, including a wide selection of $1 \mathrm{D}$ and 2D flood simulation engines [37]. Flooded regions, water depth, and stream velocities are three important hydraulic characteristics of flood, which are also the main hydrodynamic results of MIKE FLOOD [38]. The MIKE21 hydrodynamic model was used to simulate a dam-break flood with a finite volume method. When users provide bottom topography and roughness, wind field, and hydrodynamic boundary condition data, the model can calculate the water level and flow changes in each grid.

The steps for using the 2D hydraulics mathematical model to simulate flood evolution are as follows:

(1) Determine the scope of the possible maximum flood inundated areas according to the topographic feature, distribution of flood control project, and historical flood scope.

(2) Grid transform for maximum flood inundated area, set the inner boundary conditions in addition to generating the terrain data and roughness data input grid.

(3) Set the outside boundary conditions on the regional boundary grid cell (according to flood control scheduling scheme or dam-break history and obtain the corresponding flow process, water level, discharge flow process, or water flow relations, etc.).

(4) Under the premise of considering computational efficiency and precision, determine the computational time step, solve the hydraulic elements such as water depth, flow velocity, and flow direction on each grid cell for the entire basin.

(5) Obtain the submerged depth, range of maximum velocity, maximum flood range, and flood duration information about each grid cell under different dam-break schemes. 
3.3.3. Design of Flood Hazard Map Management System Framework Based on a Client/Server Structure

The design of the system framework based on a client/server (C/S) structure is shown in Figure 5. Yin et al. [12] attempted to use the browser/server structure to show the evolution process of dam flood in the browser side. This is obviously different from the conventional system design method of using the $\mathrm{C} / \mathrm{S}$ structure, whose architecture design is more suitable for coupling with the complex hydraulics model and for quick access to model calculation results. It is also much better in terms of reusability, expansibility, and integration. The systems developed with C\# language in the Visual Studio 2010 development environment were combined with the secondary developing tool of ArcEngine provided by Esri (Sacramento, CA, USA) to build the platform of the overall architecture. In this manner, the system functions were completed for dam-break flood calculation, risk mapping, disaster loss assessment, and so on. The study achieved the management of dam-break hazard mapping by integrating the entire process.

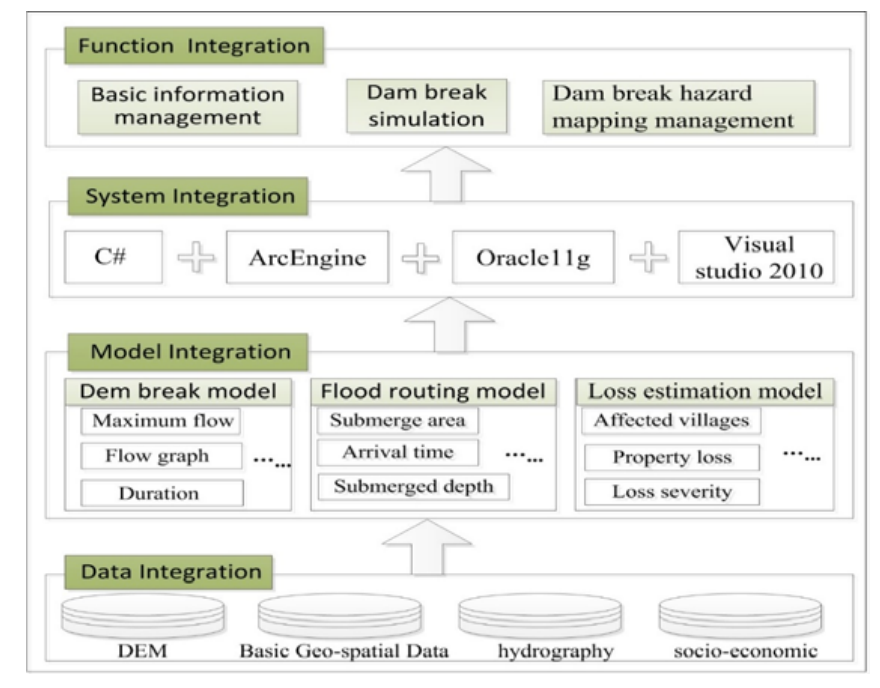

Figure 5. General structure of the system. DEM: digital elevation model.

\section{Results and Discussion}

\subsection{Analysis of Dam-Break Flood}

To reduce the threat of dam-induced floods, it is essential to understand the characteristics of probable dam-break floods in the real environment [39]. The reservoir level was calculated using the breach flow process calculation model recommended by flood risk mapping guidelines and combined with $30 \mathrm{~m}$ digital elevation model (DEM) data, under the circumstance of total collapse of a gravity dam. The water level before the dam break was $129.5 \mathrm{~m}$, with a maximum capacity of $0.496 \times 10^{9} \mathrm{~m}^{3}$ during the floor season and an upland water flow of $2000 \mathrm{~m}^{3} / \mathrm{s}$ (maximum value in history). The calculation results show that the maximum flow is $253,227 \mathrm{~m}^{3} / \mathrm{s}$ during the dam break and the time for emptying the reservoir is $2.69 \mathrm{~h}$. The MIKE21 model predicted that a total area of $1957 \mathrm{~km}^{2}$ will be inundated by the most dangerous discharge. From the depth distribution shown in Figure 6, it can be concluded that the distribution of flood never exceeds the maximum research area throughout the entire process of flood expansion, thereby proving the rationality of research area settings. After $1 \mathrm{~h}$, the maximum flow reached Lu'an City, which lies $75 \mathrm{~km}$ downstream of the breach, while the maximum flood peak arrived after $134 \mathrm{~min}$, with a maximum flow rate of $38,091 \mathrm{~m}^{3} / \mathrm{s}$. Research shows that when warnings are issued $90 \mathrm{~min}$ or more before the dam break, there was only a $0.02 \%$ death rate in the people living downstream. However, if the time of warning is less than $15 \mathrm{~min}$ before the dam break, the death rate will increase to 50\% [40]. Therefore, people living in $\mathrm{Lu}^{\prime}$ an face low threat levels under a sound 
disaster warning system, despite the $40,000 \mathrm{~m}^{3} / \mathrm{s}$ of flood peak flow reaching the average flow of Yichang Hydrological Station in Yangtze River during the flood season. The impact of large volumes of instantaneous flow may destroy houses and flood farmlands, resulting in significant casualties and property losses. Therefore, the disaster will be of a severe nature and cause overwhelming devastation.

In the visualization of the outcomes of the dam-break calculations, flooded areas are present in the shape of a horn and flooding in the upstream is limited within a small range, with a relatively higher depth. Flooding upstream and downstream are separated by the Hengshan bridge, between which the terrain differs markedly. The watercourse upstream runs through a mountainous terrain, while the downstream upstream runs through plain polder. When the dam-break flood reaches downstream, it flattens rapidly and covers a large submerged area with low inundation depths in Figure 7.
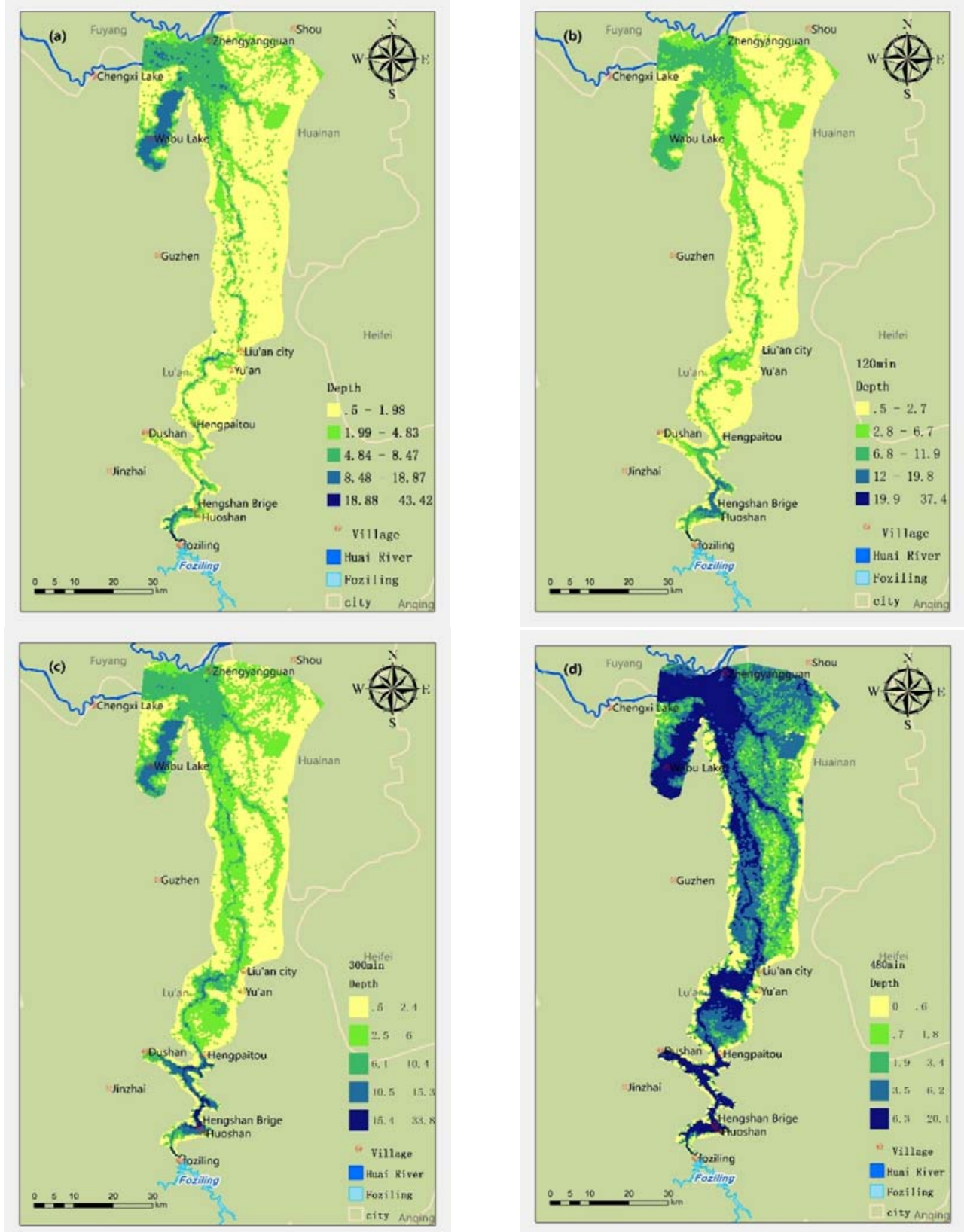

Figure 6. Distribution map of the depth of the water between $0.5 \mathrm{~h}$ and $8 \mathrm{~h}$. (a) Water depth distribution map in $0.5 \mathrm{~h}$; (b) Water depth distribution map in $2 \mathrm{~h}$; (c) Water depth distribution map in $5 \mathrm{~h}$ (d) Water depth distribution map in $6 \mathrm{~h}$. 

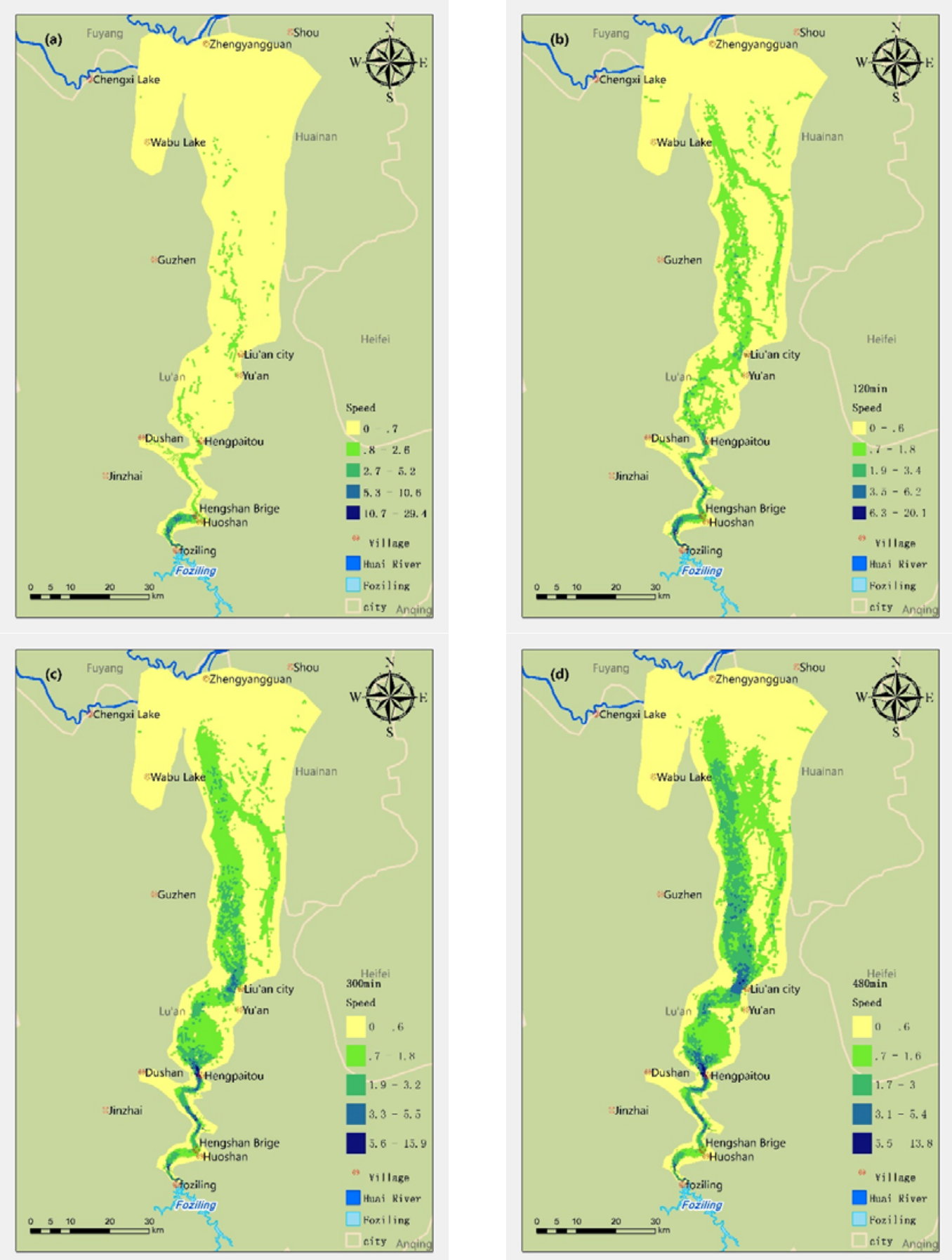

Figure 7. Distribution map of the speed of the water between $0.5 \mathrm{~h}$ and $8 \mathrm{~h}$. (a) Flow rate distribution map in 0.5 h; (b) Flow rate distribution map in 2 h; (c) Flow rate distribution map in $5 \mathrm{~h}$ (d) Flow rate distribution map in $6 \mathrm{~h}$.

By analyzing the maps of water depth and flow field distributions, the flood depth downstream near Wabu Lake and the Huai River Estuary was found to rise rapidly, then descend before rising again to gradually reach a steady state. The flow field distribution map shows that when the maximum flow of dam-break flood arrives, the flow turns towards the downstream direction, reversing upstream after some time before returning downstream again. This indicates that the flow-arising from a back-flow phenomenon under the influence of the catchment of Wabu Lake—can increase the risk of severe losses in downstream areas due to secondary flooding. 


\subsection{Flood Maps}

The spatial distribution of flooding was analyzed by preparing dam-break flooding maps along the river. These maps show the spatial extent and the depth of flooding along the Pihe River drainage basin. The flood arrival time and flood speed at different locations are given in Figure 7 . Flood maps [28,29] can show the process of flood dissemination at a certain moment after dam-break disasters, in addition to reflecting the maximum depth, last time, and flow field information of the dam-break flood. The flood field distribution map in Figure 8 shows that $0.5 \mathrm{~h}$ after of the dam break, flooding in the downstream mainly spreads inside the watercourse along the flow direction, with the flood breaking through the watercourse area over time. Under the influence of factors such as buildings, terrain, surface roughness, and flow velocity, flow direction is no longer perpendicular to the section, but instead spreads parallel to the section over time. In the meantime, the flow rises and falls constantly, with the flood reflux phenomenon occurring at some point.
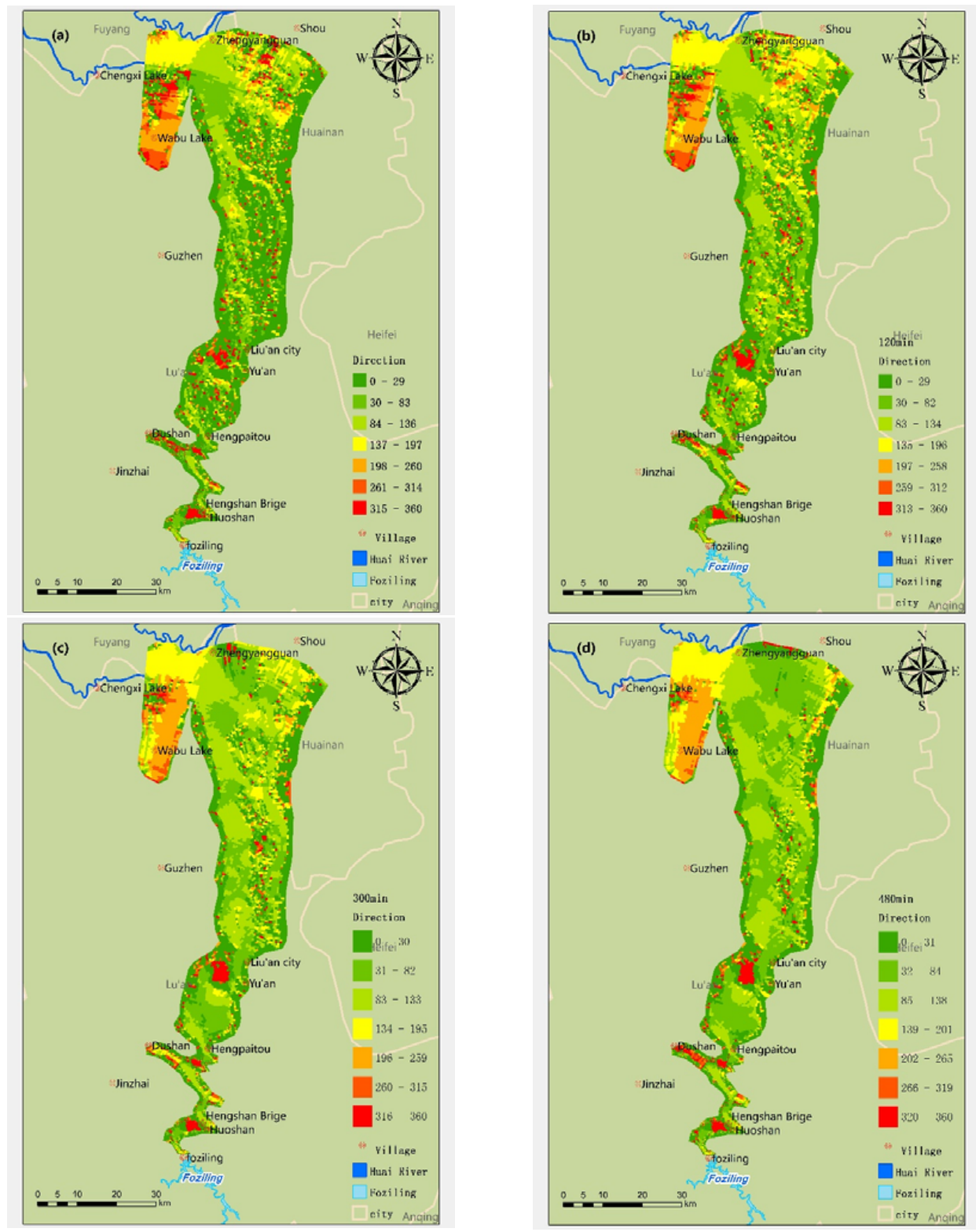

Figure 8. The flow field distribution mapping between $0.5 \mathrm{~h}$ to $8 \mathrm{~h}$. (a) Flow field distribution map in 0.5 h; (b) Flow field distribution map in 2 h; (c) Flow field distribution map in $5 \mathrm{~h}$ (d) Flow field distribution map in $6 \mathrm{~h}$. 
The research of continuous flood spreading process is vital to the prevention of secondary disaster losses caused by flood reflux. In addition to the layers of flood control material reserves, administrative region layers, socio-economic distribution layers, hedging points, and hedging route layers can be superimposed on the flood depth and flow distribution maps to generate thematic maps, such as damage assessment risk maps, disaster warning hedging maps, and disaster command operation maps. This can ultimately provide services for flood mitigation and warning.

\subsection{Dam-Break Loss Evaluation}

In accordance with the socio-economic survey data combined with inundation depth, duration of dam-break flood, and administrative division data, a disaster loss model of dam break [39,41] was built. Using this model, a comprehensive analysis of disaster loss caused by the instantaneous collapse of the Foziling reservoir was performed, with the results showing that the flooded areas included Huoshan County, Yu'an, Jin'an, Shou County, Huoqiu County, in addition to 45 villages and towns, reaching a total of $1957 \mathrm{~km}^{2}$. In the simulated dam-break disaster, 270,000 households and 996,000 people in total were affected. Commercial and industrial enterprise losses amounted to 1.511 billion CNY, while the entire housing area affected reached $2.49 \times 10^{6} \mathrm{~m}^{2}$, amounting to a loss of 4.98143 billion RMB. All household asset losses reached 186.79 million RMB. Other indirect losses, human lives, and health, in addition to ecological environment loss caused by the dam break are also significant, although they could not be accurately estimated.

\section{Conclusions}

Risk resistance against natural disasters needs to be further strengthened, because social economic levels and living standards are constantly being improved. In fact, reservoir projects are under threat from hazard risks to a large extent, with regards to engineering techniques and exceeding standard floods in certain basins. In order to lower the loss in downstream cities caused by dam failures, it is necessary to evaluate the probability of risk occurrences and the extent of the consequent damages. The assessment of such probable scenarios, along with dam-break flood simulations, can provide us with better understanding and allow for adequate preparation for such floods [30]. Based on the predictions and necessities mentioned above, and combined with the integration of hydraulic calculation models and GIS technology, this study attempted to simulate the possible scenarios of dam-break floods, the corresponding processes, and the degree of the consequent hazards in a rather complex basin environment. Computational simulations of dam-break flood and associated visualization representations were able to be realized through an effective combination of hydraulic models and GIS technology with the exploration of multi-data fusion in cases where basic watershed data were unavailable. The results effectively support the increase in efficiency and accuracy of hydraulic calculations, in addition to further providing strategies for dam failure management and emergency decision-making with scientific basis and technical support.

Based on the hydrological and geographical environment data, this paper simulates the evolution process of dam break flooding and uses GIS technology to realize the automatic drawing and management of the dam risk and flood risk map, which further improves the capacity for early warning for natural disasters. In the process of calculation, this paper did not consider the effect of watershed confluence and intermittent water supply on the water level and velocity of river channel. In the future, we should further simulate the influence of hydrological factors on the superimposition of watersheds in extreme weather conditions. As a result, a more comprehensive and scientific flood risk map will be drawn to provide a basis for watershed management.

Acknowledgments: This work was supported by the National Key Research and Development Program of China (Grant No. 2016YFC0401502) and the National Natural Science Foundation of China (Grant No. 41501558). The authors also thanks the Water Conservancy Department of Anhui Province for supporting this project. 
Author Contributions: Jian Mao conducted the primary experiments and cartography in addition to analyzing the results. Jianhua $\mathrm{Ni}$ and Changbai Xi offered data support for this work. Jiechen Wang and Shandong Wang provided the original idea for this paper.

Conflicts of Interest: The authors declare no conflicts of interest.

\section{References}

1. He, X.Y.; Wang, Z.Y.; Huang, J.C. Temporal and spatial distribution of dam failure events in China. Int. J. Sediment Res. 2008, 23, 398-405. [CrossRef]

2. Li, S.Y.; Zhou, X.B.; Wang, Y.J.; Zhou, J.P.; Du, X.H.; Chen, Z. Study of risk acceptance criteria for dams. Sci. China Technol. Sci. 2015, 58, 1263-1271. [CrossRef]

3. Armanda, S.R.; Maria, A.S.; Fernanda, R. Dam-break flood emergency management system. Water Resour. Manag. 2002, 16, 489-503.

4. Mufute, N.L.; Senzanje, A.; Kaseke, E. The development of a risk of failure evaluation tool for small dams in Mzingwane Catchment, Zimbabwe. Phys. Chem. Earth Parts ABC 2008, 33, 926-933. [CrossRef]

5. Jene, M.; Carl, J.; Judy, I.; Jillian, M. Methods for estimating the impact of hypothetical dam break floods. Chem. Prot. Environ. 2005, 4, 195-199.

6. Wang, L.H.; Hu, S.X. The summarize study of dam-break. Adv. Sci. Technol. Water Resour. 2007, $27,80-85$.

7. Xiang, L.Y. Considerations on flood hazard mapping in China. China Water Resour. 2005, 17, 9-10.

8. Brunner, G.W. HEC-RAS River Analysis System Hydraulic Reference Manual. 2010. Available online: http://www.hec.usace.army.mil/software/hec-ras/documentation/HEC-RAS_4.1_Reference_ Manual.pdf. (accessed on 10 June 2013).

9. Xiong, Y. A Dam Break Analysis Using HEC-RAS. J. Water Resour. Prot. 2011, 3, 370-379. [CrossRef]

10. Cunge, J.A. On the subject of a flood propagation computation method (Muskingum method). J. Hydraul. Res. 1969, 7, 205-230. [CrossRef]

11. Pilotti, M.; Maranzoni, A.; Milanesi, L.; Tomirotti, M.; Valerio, G. Dam-break modeling in alpine valleys. J. Mt. Sci. 2014, 11, 1429-1441. [CrossRef]

12. Yin, L.Z.; Zhu, J.; Zhang, X.; Li, Y.; Wang, J.H.; Zhang, H.; Yang, X.F. Visual analysis and simulation of dam-break flood spatiotemporal process in a network environment. Environ. Earth Sci. 2015, 74, 7133-7146. [CrossRef]

13. Li, Z.J. A synthetic method for simulating both discharge and stage of flood in a channel. Yellow River 1990, $4,16-20$.

14. Anderson, M.G. Hydrological Forecasting; John Wiley \& Sons: Hoboken, NJ, USA, 1985.

15. Bahrami, M.; Nasab, S.B.; Naseri, A.A.; Albaji, M. Comparison of Muskingum-Cunge model and irrigation hydraulic models in estimation of furrow irrigation advance phase. Res. Crops 2010, 11, 541-544.

16. Dincergok, T. The Role of Dam Safety in Dam-Break Induced Flood Management. In Proceedings of the International Conference on River Basin Management, Kos Island, Greece, 23-25 May 2007; pp. 683-691.

17. Butt, M.J.; Umar, M.; Qamar, R. Landslide dam and subsequent dam-break flood estimation using HEC-RAS model in Northern Pakistan. Nat. Hazards 2012, 65, 241-254. [CrossRef]

18. Bellos, C.V.; Sakkas, J.G. Experimental investigation of two-dimensional dam-break induced flows. J. Hydraul. Res. 1992, 30, 47-63. [CrossRef]

19. Fraccarollo, L.G.; Toro, E.F. Experimental and numerical assessment of the shallow water model for two-dimensional dam-break type problems. J. Hydraul. Res. 1995, 33, 843-864. [CrossRef]

20. Singh, V.P. Dam Breach Modeling Technology; Kluwer Academic Publisher: Dordrecht, The Netherlands, 1996; pp. 55-58.

21. Morris, M.W. CADAM: A European Concerted Action Project on Dam Break Modeling. In Proceedings of the Biennial Conference of the British Dam Society, Bath, UK, 14-17 June 2000.

22. Sarhadi, A.; Soltani, S.; Modarres, R. Probabilistic flood inundation mapping of ungauged rivers: Linking GIS techniques and frequency analysis. J. Hydrol. 2012, 458-459, 68-86. [CrossRef]

23. Huang, C.; Chen, Y.; Wu, J. Mapping spatio-temporal flood inundation dynamics at large river basin scale using time-series flow data and MODIS Imagery. Int. J. Appl. Earth Obs. Geoinform. 2014, 26, 350-362. [CrossRef] 
24. Giustarini, L.; Chini, M.; Hostache, R.; Pappenberger, F.; Matgen, P. Flood Hazard Mapping Combining Hydrodynamic Modeling and Multi Annual Remote Sensing data. Remote Sens. 2015, 7, 14200-14226. [CrossRef]

25. Dewan, A.M.; Islam, M.M.; Kumamoto, T.; Nishigaki, M. Evaluating Flood Hazard for Land-Use Planning in Greater Dhaka of Bangladesh Using Remote Sensing and GIS Techniques. Water Resour. Manag. 2006, 21, 1601-1612. [CrossRef]

26. Seker, D.Z.; Kabdasli, S.; Rudvan, B. Risk assessment of a dam-break using GIS technology. Water Sci. Technol. 2003, 48, 89-95. [PubMed]

27. Mordvintsev, A.; Krzhizhanovskaya, V.; Lees, M.; Sloot, P. Simulation of city evacuation coupled to flood dynamics. In Pedestrian and Evacuation Dynamics 2012; Springer: Cham, Switzerland, 2014; pp. 485-499.

28. Sadrolashrafi, S.S.; Thamer, A.M.; Ahmad, R.B.; Majid, K.K.; Amir, S. Integrated modeling for flood hazard mapping using watershed modeling system. Am. J. Eng. Appl. Sci. 2008, 1, 149-156.

29. Ahmad, B.; Muhammad, S.K.; Butt, M.J.; Dahri, Z.H. Hydrological modelling and flood hazard mapping of Nullah Lai. Proc. Pak. Acad. Sci. 2012, 47, 215-226.

30. Ministry of Water Resources of the People's Republic of China. Flood Risk Mapping Guidelines; SL483-2010; Ministry of Water Resources of the People's Republic of China: Beijing, China, 2010.

31. Bajabaa, S.; Masoud, M.; Al-Amri, N. Flash flood hazard mapping based on quantitative hydrology, geomorphology and GIS techniques (case study of Wadi Al Lith, Saudi Arabia). Arab. J. Geosci. 2013, 7, 2469-2481. [CrossRef]

32. Wu, Z.R.; Fan, S.P. The comprehensive analysis for multiple-arch dam prototype structural condition of foziling. Water Resour. Hydropower Eng. 1993, 11, 2-6.

33. Bajracharya, B.; Shrestha, A.B.; Rajbhandari, L. Glacial Lake Outburst Floods in the Sagarmatha Region. Mt. Res. Dev. 2007, 27, 336-344. [CrossRef]

34. Xie, R.Z. The flow calculation of Dam dam site. Waterw. Transp. Sci. Res. 1982, 1, 43-58. [CrossRef]

35. Xie, R.Z. Dam-Break Hydraulics; Shandong Science and Technology Publishing Company: Shandong, China, 1993.

36. The National Development and Reform Commission of the People's Republic of China. Code for Simulation of Dam-Break Flow for Hydropower \& Hydraulic Engineering; DL/T 5360-2006; The National Development and Reform Commission of the People's Republic of China: Beijing, China, 2007.

37. DHI. MIKE FLOOD: 1D-2D Modelling User Manual; DHI Water and Environment: Hørsholm, Denmark, 2009.

38. Jonkman, S.; van Gelder, G.P.; Vrijling, J. Loss of life models for sea and river floods. Flood Def. 2002, 1, 196-206.

39. Lodhi, M.S.; Agrawal, D.K. Dam-break flood simulation under various likely scenarios and mapping using GIS: Case of a proposed dam on River Yamuna, India. J. Mt. Sci. 2012, 9, 214-220. [CrossRef]

40. Brown, C.A.; Graham, W.J. Assessing the threat to life from dam failure. Water Resour. Bull. 1988, 24, 1303-1309. [CrossRef]

41. Cheng, C.; Qian, X.; Zhang, Y.; Wang, Q.; Sheng, J. Estimation of the evacuation clearance time based on dam-break simulation of the Huaxi dam in Southwestern China. Nat. Hazards 2010, 57, 227-243. [CrossRef]

(C) 2017 by the authors. Licensee MDPI, Basel, Switzerland. This article is an open access article distributed under the terms and conditions of the Creative Commons Attribution (CC BY) license (http://creativecommons.org/licenses/by/4.0/). 